\title{
First occurrence of a new Ocruranus-like helcionelloid mollusc from the lower Cambrian of East Gondwana.
}

\author{
By Christian B. Skovsted ${ }^{1,2}$, Glenn A. Brock ${ }^{3} \&$ Timothy P. Topper $^{3,4}$
}

${ }^{1}$ Department of Palaeozoology, Swedish Museum of Natural History, Box 50007, SE-104 05 Stockholm, Sweden [Christian.Skovsted@nrm.se]; Corresponding author.

${ }^{2}$ Department of Earth Sciences, Palaeobiology, Uppsala University, Villavägen 16, SE-752 36 Uppsala, Sweden.

${ }^{3}$ Department of Biological Sciences, Macquarie University, Sydney, New South Wales 2109, Australia [glenn.brock@mq.edu.au; timothy.topper@gmail.com].

${ }^{4}$ Geological Museum, Natural History Museum of Denmark, University of Copenhagen, Øster Voldgade 5-7, DK-1350 Copenhagen K, Denmark.

\section{Abstract}

A new cap-shaped mollusc, Emargimantus angulatus gen. et sp. nov. is described from the Arrowie Basin of South Australia. The new species is closely comparable to mollusc species from South China and North-East Greenland previously described under the generic name Ocruranus Liu, a genus recently reinterpreted as a multiplated, possibly polyplacophoran mollusc. Emargimantus is interpreted as a univalved helcionelloid mollusc and differs from Ocruranus in both morphology and function. Emargimantus angulatus represents the first discovery of Ocruranus-like helcionelloids in the lower Cambrian of eastern Gondwana and demonstrates that these molluscs had a global distribution during the early Cambrian.

Key words: Emargimantus, Helcionelloida, Ocruranus, Lower Cambrian, Gondwana. 


\section{Introduction}

Small cap-shaped shells are among the most numerous and widespread fossils in lower Cambrian rocks worldwide, in particular as phosphatised shells and internal moulds among Small Shelly Fossil assemblages (Rozanov et al. 1969; Geyer 1986; Kerber 1986; Qian \& Bengtson 1989; Bengtson et al. 1990; Elicki 1994; Esakova \& Zhegallo 1996; Gravestock et al. 2001; Wrona 2003; Skovsted 2004). Many of these shells are convincingly referred to the Helcionelloida Peel 1991, a Class of endogastrically coiled univalved molluscs, but other examples remain highly problematic both in terms of functional morphology and biological affinity.

One genus which has been extensively debated is Ocruranus Liu, 1979. This genus was originally described from the early Cambrian (Meishucunian Stage) of South China as a brachiopod (Liu 1979), but later authors referred the genus to tommotiids, polyplacophorans and coeloscleritophorans (Jiang 1980; Liu 1987; Yu 1987; Qian \& Bengtson 1989; Bengtson 1992; Siegmund 1997). Peel and Skovsted (2005) described fossil shells from the lower Cambrian of North-East Greenland very similar in morphology to at least one of the Chinese species referred to Ocruranus (originally described as Stephaconus trulliformis Jiang, 1980) and suggested that these shells represented univalved helcionelloid molluscs. Recently Vendrasco et al. (2009) revised the Chinese type species of Ocruranus and convincingly demonstrated that Ocruranus shells belong to a larger scleritome that included other skeletal elements. However, Vendrasco et al. (2009) excluded O. trulliformis from their discussion, implying that this species, as well as the Greenland specimens described by Peel \& Skovsted (2005), fall outside the concept of Ocruranus. Herein, we report the first occurrence in Gondwana of Ocruranus-like shells from the lower Cambrian of the Flinders Ranges in South Australia, closely comparable to two of the Greenland species described by Peel \& Skovsted (2005) and to S. trulliformis from China. 


\section{Localities, Age and Methods}

Phosphatised shells and internal moulds of Emargimantus angulatus gen. et sp. nov. were recovered using buffered acetic acid (10\%) in the Macquarie University Acid Leaching Facility. The material is derived from two samples (AJX-M 281.6 and 282) collected from a grey to buff bioclastic (commonly silicified) and nodular mottled limestone equivalent to 157.47 $\mathrm{m}-157.69 \mathrm{~m}$ above the base of the stratigraphic section measured through the Ajax Limestone in the Mt. Scott Range (equivalent to section M of Gravestock 1984, fig. 2) (Fig. 1C). The base of the AJX-M section is located at coordinates $30^{\circ} 35^{\prime} 49^{\prime \prime} \mathrm{S}, 138^{\circ} 19^{\prime} 59.3^{\prime \prime} \mathrm{E}$ [WGS84]. The stratigraphy and lithology of the Ajax Limestone at section AJX-M (Fig 1) has been summarised by Brock et al. (2006) and Topper et al. (2011b, fig. 2). The carbonatedominated Ajax Limestone at AJX-M conformably overlies the siliciclastic Parachilna Formation. Archaeocyaths were described by Gravestock (1984) and Bengtson et al. (1990, fig. 6) documented a variety of taxa including trilobites, molluscs, sponge spicules and SSFs from the AJX-M section. More recently, the stem group brachiopod Mickwitzia (Skovsted et al. 2009), the tommotiid Eccentrotheca (Skovsted et al. 2011a), fused sclerites of the problematic taxon Stoibostrombus (Skovsted et al. 2011b), Microdictyon lobopod plates (Topper et al. 2011a) and a bivalved arthropod assemblage (Topper et al. 2011b) have been documented from this stratigraphic section.

The stratigraphic levels containing Emargimantus angulatus gen. et sp. nov. also host the trilobite Abadiella huoi, which is the eponym of the oldest trilobite zone in South Australia (see Jago et al. 2006; Paterson \& Brock 2007). The Abadiella huoi trilobite biozone, broadly correlates with the Parabadiella trilobite Zone in South China (Jago et al. 2006; Paterson and Brock, 2007) and the Atdabanian Stage of Siberia (Zhuravlev and Gravestock, 1994; Zhuravlev, 1995). 
A single specimen of E. angulatus was also recovered from an insoluble residue of a sample collected in Bunyeroo Gorge (BUN 9) by the late Brian Daily in the 1960s and recollected in the early-mid 1970s (Fig. 1D). This sampleis part of a large number of picked (but largely unsorted) microfossil residues recently transferred to the collections of the South Australian Museum. Exact stratigraphic details for most of Daily's field samples can be pinpointed with a fair degree of accuracy from detailed descriptions found in his comprehensive field note books (also held in the collections of the South Australian Museum). Sample BUN 9 comes from a series of samples, obviously from a measured stratigraphic section in Bunyeroo Gorge, but locating the exact stratigraphic horizon is somewhat difficult. However, the co-ocurring fauna includes abundant specimens of Micrina etheridgei (Tate, 1892) Dailyatia ajax Bischoff, 1976, D. macroptera (Tate, 1892) and Askepasma toddense Laurie, 1986 which are commonly associated with the A. huoi trilobite zone in other sections in the Flinders Ranges, most notably the Winnitinny Creek Member of the upper Wilkawillina Limestone (Paterson and Brock 2007). All illustrated specimens were mounted on self adhesive carbon tabs and coated with gold prior to SEM investigation at the Museum of Natural History in Stockholm.

\section{Emargimantus as a helciolelloid mollusc}

The recent redescription and analysis by Vendrasco et al. (2009) of the type species of Ocruranus, O. finial Liu, 1979 and associated shells from South China resulted in a multicomponent reconstruction of Ocruranus as a possible stem group polyplacophoran, incorporating Eohalobia Jiang, 1982 and previously undescribed shells in its scleritome. The occurrence of Ocruranus in the Bastion Formation of North-East Greenland (Peel \& Skovsted 2005) was discussed by Vendrasco et al. (2009), who concluded that no shells comparable to Eohalobia or the other components of the Ocruranus scleritome were associated with 
Ocruranus at this locality, despite detailed investigation of the co-occurring fauna (i.e.

Skovsted 2004, 2006; Malinky \& Skovsted 2004 and references therein). This observation, together with morphological differences between the Greenland species and $O$. finial (i.e. the lack of obvious articulating surfaces) led Vendrasco et al. (2009) to conclude that the Greenland species were probably not closely related to Ocruranus. Similar arguments apply to the Chinese species Stephaconus trulliformis (see discussion below) despite its reassignment to Ocruranus by Qian \& Bengtson (1989) as well as the Australian species Emargimantus angulatus gen. et sp. nov. described herein. All available evidence currently indicates that the four species of Emargimantus recognized here were not associated with other skeletal components in a multi element skeleton. The shell of Emargimantus further differs from Ocruranus by the high, conical shape and the well developed sub-apical apron without a sub-apical shelf or any other obvious articulating structures.

In terms of shell morphology the four species of Emargimantus conform to the general concept of the univalved molluscan Class Helcionelloida Peel, 1991. The cap-shaped, bilaterally symmetrical shell morphology, sub-circular dorsal outline, slightly overhanging apex, sub-apical apron with a shallow apertural emargination are common features among helcionelloids, although the emargination of the shell is more commonly associated with laterally compressed shells. For these reasons, we conclude that Emargimantus represents a member of the Helcionelloida and that any similarities to Ocruranus are likely to be convergent.

\section{Observations on the biogeographic and stratigraphic distribution of}

\section{Emargimantus}

The discovery of Emargimantus in the Arrowie Basin represents the first report of this type of mollusc in East Gondwana and demonstrates that this genus had a more or less global 
distribution in the lower Cambrian. The geographic distribution of early Cambrian molluscs is still insufficiently understood, but a general pattern of widespread, even global, distribution of many mollusc taxa is developing for the early Cambrian (Gubanov 2002; Vendrasco et al. 2011), a pattern that may also apply to some early Cambrian organophosphatic brachiopods (Skovsted 2006; Skovsted et al. 2009). In particular, faunal ties between Laurentia and Gondwana have been shown to be particularly strong for late early Cambrian molluscs (Gubanov et al. 2004; Skovsted 2004, 2006; Elicki 1994, 2005) and the discovery of closely related species of Emargimantus in Laurentia and East Gondwana further strengthens this general pattern. The wide geographical distibution of many molluscan taxa contrasts sharply with the largely endemic trilobite, archaeocyath and bradoriid faunas in the lower Cambrian (Debrenne et al. 1999; Kruse \& Shi in Brock et al. 2000; Geyer \& Shergold 2000; Topper et al. 2011b).

The stratigraphic distribution of Emargimantus spans most of the traditional lower Cambrian with FAD in the Zhongyicun member of the Zhujiaqing Formation at Meishucun in South China (Qian \& Bengtson 1989; probably equivalent to the Nemakit-Daldynian Stage of Siberia; Steiner et al. 2007) to LAD in the upper Bastion Formation of North-East Greenland (middle Dyeran Stage, probably equivalent to the Botoman Stage of Siberia; Skovsted 2006). The longevity of the genus is remarkable, but is mirrored by several other helcionelloid genera from the lower Cambrian, such as Anabarella Vostokova, 1962 and Bemella Missarzhevsky in Rozanov et al., 1969, both of which also have similarly long stratigraphic ranges (Gravestock et al. 2001; Gubanov et al. 2004).

\section{Systematic Palaeontology}

Phylum Mollusca Cuvier, 1797 
Class Helcionelloida Peel, 1991

Order and Family uncertain

Genus Emargimantus gen. nov.

$1980 \quad$ Stephaconus; Jiang; (nomen nudum)

Partim 1989 Ocruranus Liu; Qian \& Bengtson, p. 103.

Partim 2005 Ocruranus Liu; Peel \& Skovsted, p. 463.

Type species. Emargimantus angulatus gen. et sp. nov.

Diagnosis. Cap-shaped helcionelloid with circular to sub-circular outline; rapidly expanding shell coiled through up to about $1 / 4$ of a whorl. Sub-apical surface drawn out into an apron with a shallow central emargination.

Etymology. From latin emarginatus (notched) and mantele (napkin), referring to the apronlike sub-apical field with a shallow emargination.

Species included. Type species; Stephaconus trulliformis Jiang, 1980; Ocruranus septentrionalis (Peel \& Skovsted, 2005); O. tunuensis (Peel \& Skovsted, 2005) and possibly Ocruranus sp. of Peel \& Skovsted 2005.

Remarks. The genus Stephaconus was proposed by Jiang (1980) for cap-shaped shells from the Meishucunian Stage of South China. In his original publication, Jiang (1980) included two species in the new genus Stephaconus, but failed to provide a proper diagnosis for the type species (S. trulliformis), only referring back to the generic diagnosis. Since the genus was not 
monotypic, this practice means that the formal status of the genus Stephaconus and the type species $S$. trulliformis is problematic. This matter was discussed at some length by Qian \& Bengtson (1989, p. 107), who concluded that the diagnosis only applies to S. trulliformis, making the generic name Stephaconus unavailable according to ICZN rules. Qian \& Bengtson (1989) referred S. trulliformis to an older genus, Ocruranus Liu, 1979, meaning that even if it had been available, the generic name Stephaconus would have been a junior synonym of Ocruranus. However, Vendrasco et al. (2009) found no evidence in favour of S. trulliformis belonging to a multi-element skeleton of Ocruranus and we suggest this shell is much more closely comparable to the cap-shaped shells of typical helcionelloid molluscs. Following the reinterpretation of $S$. trulliformis as fundamentally different from the type species of Ocruranus, O. finial Liu, 1979 and the identification of congeneric material from Greenland and Australia, the nomenclatural problems concerning Stephaconus become more complicated. Herein we follow Qian \& Bengtson (1989) in regarding the original diagnosis as referring to the type species, $S$. trulliformis, and consequently introduce the new generic name Emargimantus to accommodate the new Australian species described below as well as the material from Greenland and S. trulliformis from China.

Emargimantus is similar in general morphology to a number of rapidly expanding low cone- or cap-shaped helcionelloid shells with a sub-circular apertural cross section. It differs from Helcionella Grabau \& Shimer, 1909, Tannuella Missarzhevsky in Rozanov et al., 1969, Marocella Geyer 1986 and similar genera by the lack of rugae or other coarse co-marginal ornament; though fine growth lines are present. Emargimantus can be discriminated from Bemella, Latouchella Cobbold, 1921 and similar taxa by the non-planar aperture. The elongated apron and sub-apical emargination of Emargimantus is similar to the sub-apical "parietal train" or "siphonal groove" (sensu Parkhaev 2002) present in Anabarella, Trenella Parkhaev, 2001, Capitoconus Skovsted, 2004 and similar taxa - all of which are relatively 
strongly compressed laterally. The combination in Emargimantus of a sub-circular aperture with a sub-apical apron and emargination is unique among helcionelloids.

Ilsanella compressa Zhegallo in Voronin et al., 1982 from the lower Cambrian (Tommotian Stage equivalent) of Mongolia was compared to Stephaconus trulliformis by Qian \& Bengtson (1989). Although the shells are similar in general morphology, we note that the nature of the sub-apical emargination is not well known for I. compressa and that insufficient evidence is available to evaluate its affinity to Emargimantus.

The internal relationships of the Helcionelloida remain uncertain, despite the efforts of Parkhaev (2002) to formulate a unified classification of all Cambrian univalved molluscs. The majority of helcionelloid taxa are only known from internal moulds or from imperfectly preserved material, and the small shell size and relatively simple morphologies of many taxa does not yield enough characters for a reliable phylogenetic analysis. The lack of preserved morphological details have even led to a long debate over basic functional interpretations of helcionelloid molluscs, most notably the orientation of the shell in relation to the soft parts with both endogastric (i.e. shell coiling backwards; Peel 1991a, b) and exogastric (i.e. shell coiling forwards; Runnegar 1996) models proposed. More recently, evidence that some helcionellid shells represent the larval stage of larger and morphologically very different molluscs, have made the picture even more complicated (Martí Mus et al. 2008). Presently it is probably more realistic to consider helcionellids as a heterogeneous molluscan stem group from which more familiar mollusc groups diverged during the Cambrian Period (see Vendrasco et al. 2011 for a recent application of this approach). Consequently, the proposed higher classification of Parkhaev, which is largely dependent on relatively minor modifications of coiling or apertural outline, remains to be tested 
Figures 2, 3

Holotype. SAMP 46309; phosphatised shell; Fig. 2A-C

Diagnosis. Species of Emargimantus with sub-central apex; shell length exceeds width by around 10\%; sub-apical area defined by narrow spiral cords on each lateral side; sub-apical surface truncated with two prominent radial folds and a very shallow emargination. Differs from all other species of Emargimantus by the two radial folds that divide the sub-apical surface.

Etymology. Angulatus (Latin) for the angular corners formed by the radial folds of the subapical surface as seen in dorsal view.

Material. Six specimens (two internal moulds and four phosphatised shells) from the Ajax Limestone, Mt. Scott Range, South Australia; one phosphatised shell from Winnitinny Creek Member of the Wilkawillina Limestone, Bunyeroo Gorge, Flinders Ranges, South Australia.

Description. Cap-shaped helcionelloid coiled through up to about $1 / 4$ of a whorl. The rounded apex slightly overhangs the sub-apical surface (Fig. 2C, F, I). The shell is almost equidimensional, with shell width about $90 \%$ and shell height $85 \%$ of shell length. The shell is divided into sub-apical and supra-apical surfaces by prominent spiral cords on the lateral surfaces (Figs 2C, F, I, 3C). The supra-apical surface defines a gently curved semi-circle in dorsal view (Figs 2B, E, 3B) and the sub-apical surface is slightly longer, extending into a wide apron bearing two well developed radial folds (Figs 2A, D, G, H). The area between the folds is truncated and developed into a flat plate, whilst the regions between the spiral cords 
and radial folds are gently concave, resulting in a key-hole like profile of the shell in dorsal view (Figs 2B, 3B). The aperture is planar, except for the broad sub-apical emargination stretching between the sub-apical folds and reaching about $15 \%$ of shell height (Figs $2 \mathrm{~A}$, $3 \mathrm{~A})$.

Remarks. Emargimantus angulatus differs from the Chinese species, E. trulliformis, by the presence of sub-apical folds and spiral cords on the lateral surfaces. The new species is closely comparable to E. tunuensis from North-East Greenland, which also exhibits prominent spiral cords on lateral surfaces (Peel \& Skovsted 2005), but E. angulatus is distinguished by a more strongly overhanging apex and the presence of angular ribs on the sub-apical surface. The second Greenland species, E. septentrionalis, only known from a single internal mould (Peel \& Skovsted 2005), is characterized by an overhanging apex and the presence of subapical folds. However, E. septentrionalis has a more complicated pattern of sub-apical folds combining positive and negative folds that result in a wavy profile of the sub-apical surface in dorsal view. Emargimantus septentrionalis also has a narrow emargination on the supraapical surface which lack counterpart in E. angulatus. Specimens from North-East Greenland described as Ocruranus sp. by Peel \& Skovsted (2005) are small cap-shaped shells with a deep notch in the sub-apical surface but few other diagnostic characters. These shells may belong to Emargimantus, but their relationship to the described taxa remains uncertain.

Oikozetetes sp., described by Paterson et al. (2009) from the MMF section measured through the Mernmerna Formation ( Pararaia bunyerooensis trilobite Zone - see Topper et al. 2009) in the central Flinders Ranges, is superficially similar to Emargimantus in the presence of a distinct sub-apical field with an emargination. However, Oikozetetes sp. differs fundamentally from Emargimantus by the lack of an overhanging apex and in the short, subapical field which is much shorter than the supra-apical part of the shell and separated from 
the shell by a narrow neck (Paterson et al. 2009, fig. 2). Paterson et al. (2009) suggested a halkieriid affinity for Oikozetetes sp., and the similarities to Emargimantus in gross shell morphology are probably superficial.

Occurrence. Specimens recovered from horizons located 157.47-157.69 $\mathrm{m}$ above base of the Ajax Limestone (Abadiella huoi trilobite Zone) in the AJX-M stratigraphic section, Mt. Scott Range and an unidentified horizon in the Winnitinny Creek Member of the Wilkawillina Limestone cropping out in Bunyeroo Gorge, both localities in the central Flinders Ranges, Arrowie Basin, South Australia.

\section{Acknowledgements}

We thank Mr Graham Ragless of Beltana Station for access to the locality at Mt. Scott and the South Australian Museum for the availability of collections from Bunyeroo Gorge made by the late Brian Daily. J. R. Paterson, B. Jonak, M. Fuller, R. Callow, P. Cockle are thanked for assistance in the field. J. S. Peel, A. R. Kouchinsky, S. Bengtson and J.R. Laurie are thanked for valuable discussions on Cambrian mollusc faunas and systematic nomenclature. Funds from the Swedish Research Council (VR) to CBS and a Macquarie University Research Development Grant to GAB are gratefully acknowledged.

\section{References}

Bengtson, S., 1992. The cap-shaped Cambrian fossil Maikhanella and the relationship between coeloscleritophorans and molluscs. Lethaia, 25, 401-420. 
Bengtson, S., Conway Morris, S., Cooper, B.J., Jell, P.A., Runnegar, B.N., 1990. Early

Cambrian fossils from South Australia. Association of Australasian Palaeontologists, Memoir 9, 364 pp.

Brock, G.A., Engelbretsen, M.J., Jago, J.B., Kruse, P.D., Laurie, J.R., Shergold, J.H., Shi,

G.R., Sorauf, J.E., 2000. Palaeobiogeographic affinities of Australian Cambrian faunas. Association of Australasian Palaeontologists, Memoir 23, 1-61.

Cobbold, E.S., 1921. The Cambrian horizons of Comley (Shropshire) and their Brachiopoda, Pteropoda, Gastropoda, etc. Quarterly Journal of the Geological Society of London, 76, $325-386$.

Elicki, O., 1994. Lower Cambrian carbonates from eastern Germany: Palaeontology, stratigraphy and palaeogeography. Neues Jahrbuch für Geologie und Paläontologie Abhandlungen B, 191, 69-93.

Elicki, O., 2005. The utility of late Early to Middle Cambrian small shelly fossils from the western Mediterranean. Geosciences Journal, 9, 161-171.

Esakova, N.V., Zhegallo, E.A., 1996. Biostratigrafiya i fauna nizhnego kembriya Mongolii (Lower Cambrian biostratigraphy and fauna of western Mongolia). Trudy, Sovmestnaya Rossiysko-Mongol’skaya paleontologicheskaya ekspeditsiya, 46, 214 pp. (in Russian).

Geyer, G., 1986. Mittelkambrische Mollusken aus Marokko und Spanien. Senckenbergiana lethaea, 67, 55-118.

Grabau, A.W., Shimer, H.W., 1909. North American index fossils, invertebrates. A.G. Seiler \& Company, New York. 909 pp.

Gravestock, D.I., 1984. Archaeocyatha from lower parts of the Lower Cambrian carbonate sequence in South Australia. Memoir of the Association of Australasian Palaeontologists, 2, $139 \mathrm{pp}$. 
Gravestock, D.I., Alexander, E.M., Demidenko, Yu.E., Esakova, N.V., Holmer, L.E., Jago, J.B., Lin, T.R., Melnikova, L.M., Parkhaev, P.Yu., Rozanov, A. Yu., Ushatinskaya, G.T., Zang, W.L., Zhegallo, E.A., Zhuravlev, A.Yu., 2001. The Cambrian biostratigraphy of the Stansbury Basin, South Australia. Transaction of the Palaeontological Institute, 282, 344 pp.

Gubanov, A.P., 2002. Early Cambrian palaeogeography and the probable Iberia-Siberia connection. Tectonophysics, 352, 153-168.

Gubanov, A.P., Skovsted, C.B., Peel, J.S., 2004. Anabarella australis (Mollusca, Helcionelloida) from the Lower Cambrian of Greenland. Geobios, 37, 219-224.

Jiang, Z.W., 1980. Monoplacophorans and gastropods fauna of the Meisuchunian Stage from the Meisuchunian section, Yunnan. Acta Geologica Sinica, 1980, 112-123 (In Chinese with English summary).

Jiang Z.W., 1982. Small shelly fossils. In: Luo H.L., Jiang Z.W., Wu X., Song X.L., Lin, O.Y., Zhang S., Luo W.C., Xue X.F., Li P., Liang Q.Z., Xie Y.H., Li X. (eds.). The Sinian-Cambrian boundary in eastern Yunnan, China. Yunnan Institute of Geological Sciences, Kunming, China, 163-200.

Kerber, M., 1988. Mikrofossilien aus unterkambrischen Gesteinen der Montagne Noire, Frankreich. Palaeontographica A, 202, 127-203.

Liu D.Y., 1979. Earliest Cambrian Brachiopods from southwest China. Acta Palaeontologica Sinica, 18, 505-511 (In Chinese).

Liu D.Y., 1987. Brachiopods and tommotiids near Precambrian-Cambrian boundary in SW China. In: Zhang, W.T., (ed.). Stratigraphy and Paleontology of systemic boundaries in China: Precambrian-Cambrian boundary. Nanjing Institute of Geology and Paleontology, Academica Sinica, Nanjing University Publishing House, Nanjing, China, $345-400$. 
Malinky, J.M., Skovsted C.B., 2004. Hyoliths and small shelly fossils from the Lower Cambrian of North-East Greenland. Acta Palaeontologia Polonica, 49, 551-578. Martí Mus, M., Palacios, T., Jensesen, S., 2008. Size of the earliest molluscs: Did small helcionellids grow to become large adults? Geology, 36, 175-178.

Parkhaev, P.Yu., 2001. Trenella bifrons - novyy gel'tsionellidnyy mollyusk iz botomskogo yarusa Yuzhnoy Avstralii (Trenella bifrons: A new helcionelloid mollusc from the Lower Cambrian of South Australia). Paleontologicheskii Zhurnal, 2001 (6), 22-24 (in Russian, English translation in Paleontological Journal 35, 585-588).

Parkhaev, P.Yu., 2002. Filogeniya i sistematik kembriyskikh odnostvorchatykh mollyuskov (Phylogeny and systematics of Cambrian univalve molluscs). Paleontologicheskii Zhurnal, 2002 (1), 27-39 (in Russian, English translation in Paleontological Journal 36, 25-36)

Paterson, J.P., Brock, G.A., 2007. Early Cambrian trilobites from ‘Angorichina', Flinders Ranges, South Australia, with a new assemblage from the Pararaia bunyerooensis Zone. Journal of Paleontology, 81, 116-142.

Paterson, J.R., Brock, G.A., Skovsted, C.B., 2009. Oikozetetes from the early Cambrian of South Australia: implications for halkieriid affinities and functional morphology. Lethaia, 42, 199-203.

Peel, J.S., 1991a. Functional morphology of the Class Helcionelloida nov., and the early evolution of the Mollusca. In: Simonetta, A.M., Conway Morris, S. (eds). The early evolution of Metazoa and the significance of problematic taxa, Cambridge University Press, Cambridge, United Kingdom, 157-177.

Peel, J.S., 1991b. The Classes Tergomya and Helcionelloida, and early molluscan evolution. Grønlands Geologiske Undersøgelse, Bulletin, 161, 11-65. 
Peel, J.S., Skovsted, C.B., 2005. Problematic capshaped fossils from the Lower Cambrian of North-East Greenland. Paläontologische Zeitschrift, 79, 461-470.

Qian Y., Bengtson, S., 1989. Palaeontology and biostratigraphy of the Early Cambrian Meishucunian Stage in Yunnan Province, South China. Fossils and Strata, 24, 156 pp. Rozanov, A.Yu., Missarzhevsky, V.V., Volkova, N.A., Voronova, L.C., Krylov, I.N., Keller, B.M., Korolyuk, I.K., Lendzion, K., Michniak, R., Pykhova, N.G., Sidorov, A.D., 1969. Tommotskij yarus i problema nizhnej grantisy kembriya. (The Tommotian Stage and the Cambrian lower Boundary problem). Trudy Geologocheskogo Instituta Akademia Nauk SSSR, 206, 380 pp. (in Russian).

Runnegar, B., 1996. Early evolution of the Molusca: The fossil record. In: Taylor, J. (ed.).

Origin and evolutionary radiation of the Mollusca, Oxford University Press, Oxford, United Kingdom, 77-87.

Siegmund, H., 1997. The Ocruranus-Eohalobia group of small shelly fossils from the Lower Cambrian of Yunnan. Lethaia, 30, 285-291.

Skovsted, C.B., 2004. Mollusc fauna of the Early Cambrian Bastion Formation of North-East Greenland. Bulletin of the Geological Society of Denmark, 51, 11-37.

Skovsted, C.B., 2006. Small shelly fauna from the upper lower Cambrian Bastion and Ella Island formations, North-east Greenland. Journal of Paleontology, 80, 1087-1112.

Skovsted, C.B, Brock, G.A., Holmer, L.E., Paterson, J.R., 2009. First report of the Early Cambrian stem group brachiopod Mickwitzia from East Gondwana. Gondwana Research 16, 145-150.

Skovsted, C.B., Brock, G.A., Topper, T.P., 2011a. Sclerite fusion in the problematic early Cambrian spine-like fossil Stoibostrombus from South Australia. Bulletin of Geosciences, 86 . 
Skovsted, C.B., Brock, G.A., Topper, T.P., Paterson, J.P., 2011b. Scleritome construction, biofacies, biostratigraphy and systematics of the tommotiid Eccentrotheca helenia sp. nov. from the early Cambrian of South Australia. Palaeontology, 54, 253-286.

Steiner, M., Li, G.X., Qian, Y., Zhu, M.Y., Erdtmann, B.D., 2007. Neoproterozoic to early Cambrian small shelly fossil assemblages and a revised biostratigraphic correlation of the Yangtze Platform (China). Palaeogeography, Palaeoclimatology, Palaeoecology, 254, 67-99.

Topper, T.P., Brock, G.A., Skovsted, C.B., Paterson, J.R., 2009. Shelly fossils from the lower Cambrian Pararaia bunyerooensis Zone, Flinders Ranges, South Australia. Memoirs of the Association of Australasian Palaeontologists, 37, 199-246.

Topper, T.P., Brock, G.A., Skovsted, C.B., Paterson, J.R., 2011a. Microdictyon plates from the lower Cambrian Ajax Limestone of South Australia: implications for species taxonomy and diversity, Alcheringa, 35, 427-443.

Topper, T.P., Skovsted, C.B., Brock, G.A., Paterson, J.R., 2011b. The oldest bivalved arthropods from the early Cambrian of South Australia: systematics, biostratigraphy and biogeography. Gondwana Research, 19, 310-326.

Vendrasco, M.J., Kouchinsky, A.V., Porter, S.M., Fernandez, C.Z., 2011. Phylogeny and escalation in Mellopegma and other Cambrian molluscs. Palaeontologia Electronica, 14, 2; 11A, palaeo-electronica.org/2011_2/221/index.html.

Vendrasco, M.J. Li, G.X., Porter, S.M., Fernandez, C.Z., 2009. New data on the enigmatic Ocruranus-Eohalobia group of Early Cambrian Small Skeletal Fossils. Palaeontology, $52,1373-1396$.

Voronin, A.Yu., Voronova, L.G., Grigor'eva, N.V., Drozdova, N.A., Zhegaloo, E.A., Zhuravlev, A.Yu, Ragozina, A.L., Rozanov, A.Yu., Sayutina, T.A., Sysoev, V.A., Fonin, V.D., 1982. Granitsa dokembriya i kembriya v geosinklinal'nykh oblastyakh 
(opomyj razrez Salany-Gol, M.N.R.) (The Precambrian-Cambrian boundary in the geosynclinal regions (reference section Salany-Gol, MNR)). Trudy Sovmestnoj sovestko-mongol'skoj paleontologicheskoj ekspeditsiya, 18, 156 pp. (In Russian). Vostokova, V.A., 1962. Kembriyskie gastropody Sibirskoy platformy i Taymyra (Cambrian gastropods of the Siberian Platform and Taimyr). Trudy Nauchno Issledovatel'skogo Instituta Geologii Arktiki, 28, 51-74. (In Russian).

Wrona, R., 2003. Early Cambrian mollusks from glacial erratics of King George Island, West Antarctica. Polish Polar Research, 24, 181-216.

Yu W., 1987, Yangtze micromolluscan fauna in Yangtze region of China with notes on Precambrian-Cambrian boundary. Nanjing Institute of Geology and Palaeontology, Academia Sinica, Nanjing, Nanjing University Publishing House, 255 pp.

Zhuravlev, A. Yu., Gravestock, D.I., 1994. Archaeocyaths from Yorke Peninsula, South Australia and archaeocyathan Early Cambrian zonation. Alcheringa, 18, 1-54.

Zhuravlev, A. Yu., 1995. Preliminary suggestions on the global Early Cambrian zonation. In: Geyer, G., Landing, E. (Eds.), MOROCCO '95-The Lower-Middle Cambrian standard of western Gondwana, Beringeria Special Issue 2. Freunde der Würzburger Geowissenschaften e. V., Wurzberg, pp. 147-160. 
Figure Captions

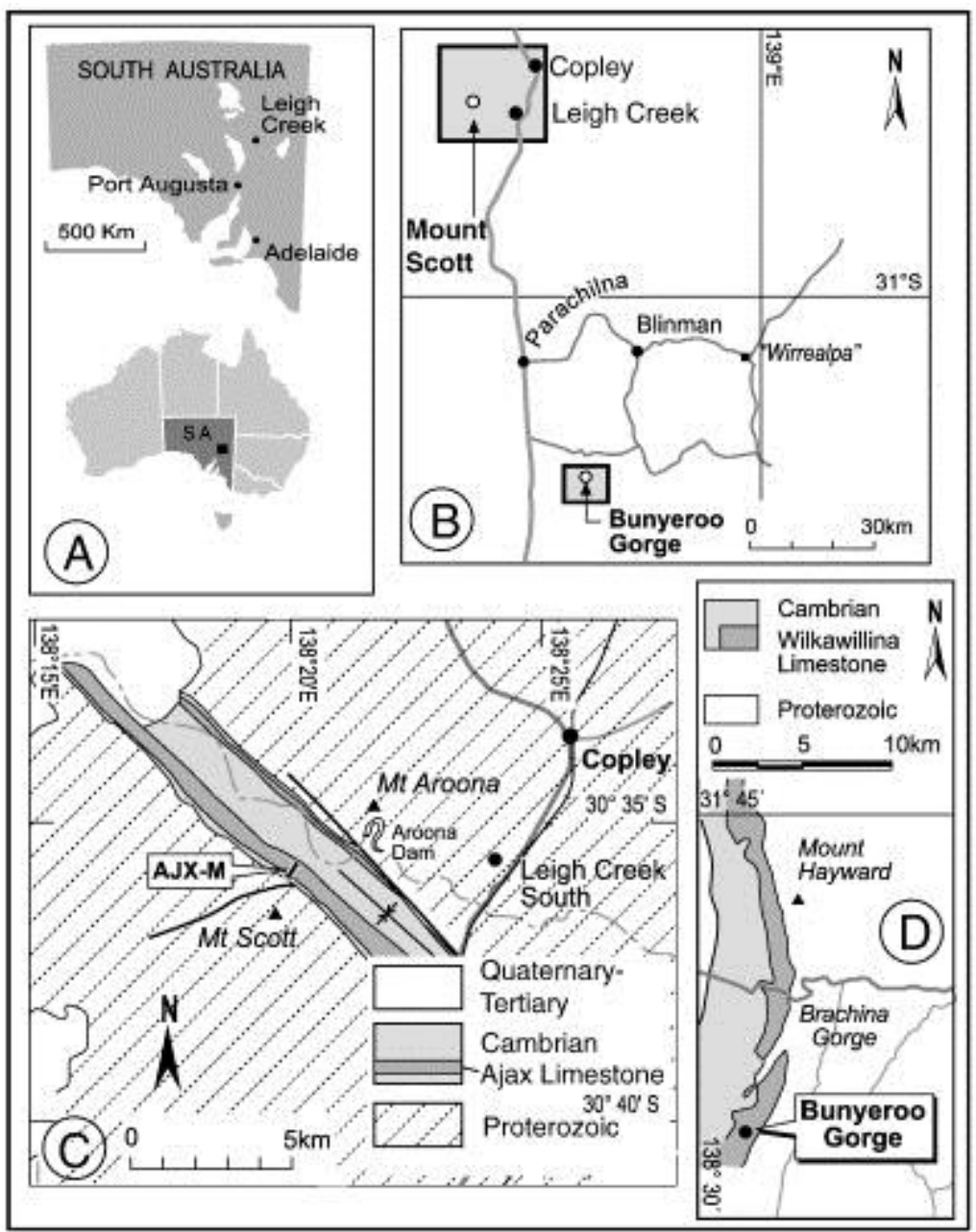

Figure 1 : Map of field areas with fossil localities indicated. A, map of Australia and South Australia with Flinders Ranges marked. B, map of central Flinders Ranges with field areas indicated. C, simplified geological map of Mt. Scott area with the position of section AJX-M indicated. D, simplified geological map of the Brachina Gorge area with the location of Bunyeroo Gorge indicated. 


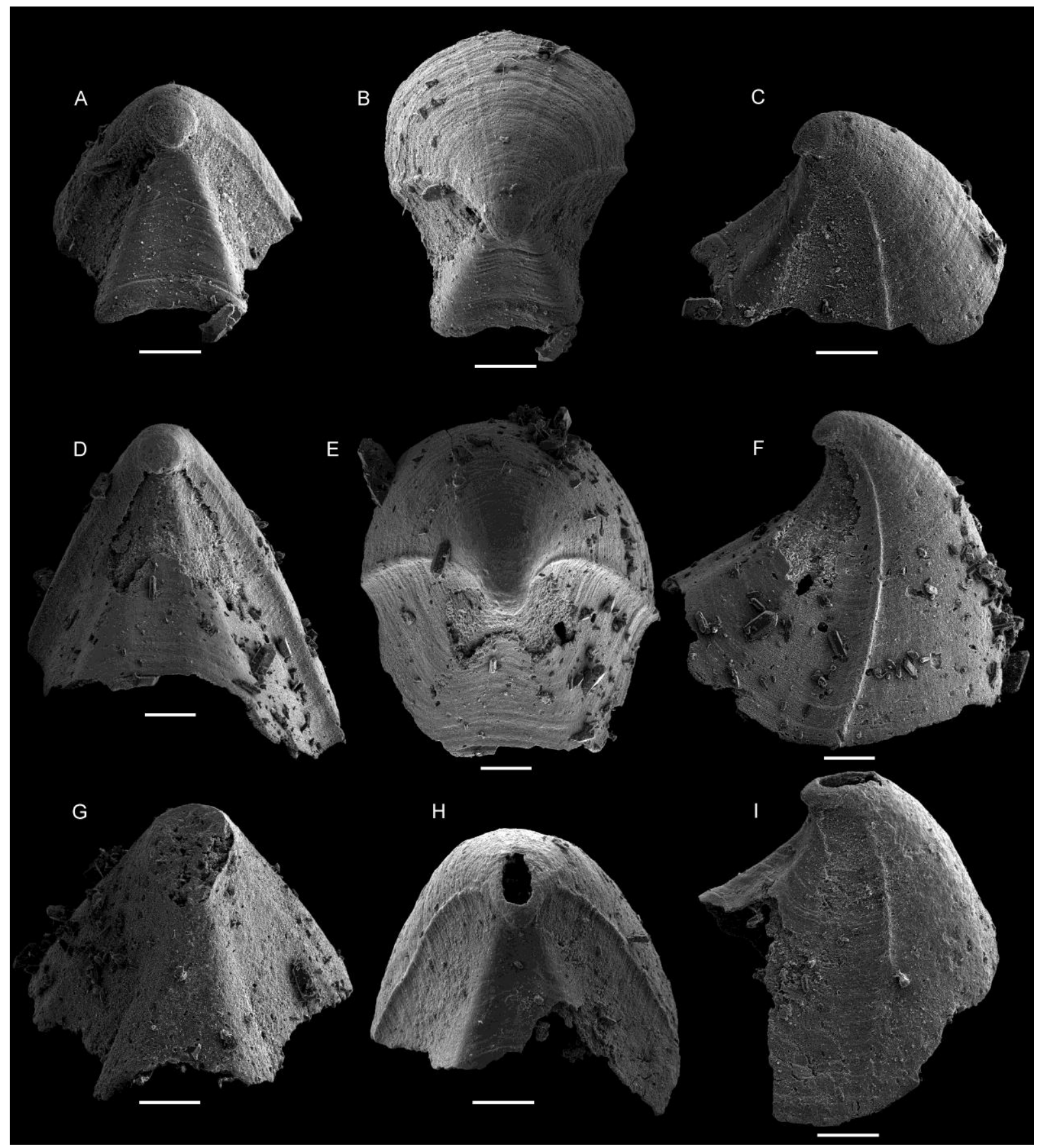

Figure 2 : Emargimantus angulatus gen. et sp. nov. Abadiella huoi Zone, Ajax Limestone at Mt. Scott, Central Flinders Ranges, Arrowie Basin, South Australia. A-C, holotype, SAMP 46309, sample AJX-M 282, phosphatised shell; A, view of sub-apical side; B, apical view; C, right lateral view. D-F, SAMP 46310, sample AJX-M 281.6, phosphatised shell; D, view of sub-apical side; E, apical view; F, right lateral view. G, SAMP 46311, sample AJX-M 281.6, internal mould viewed from sub-apical side. H, I, SAMP 46312, sample AJX-M 281.6, 
phosphatised shell; H, view of sub-apical side; I, right lateral view. All scale-bars equal 200 $\mu \mathrm{m}$.

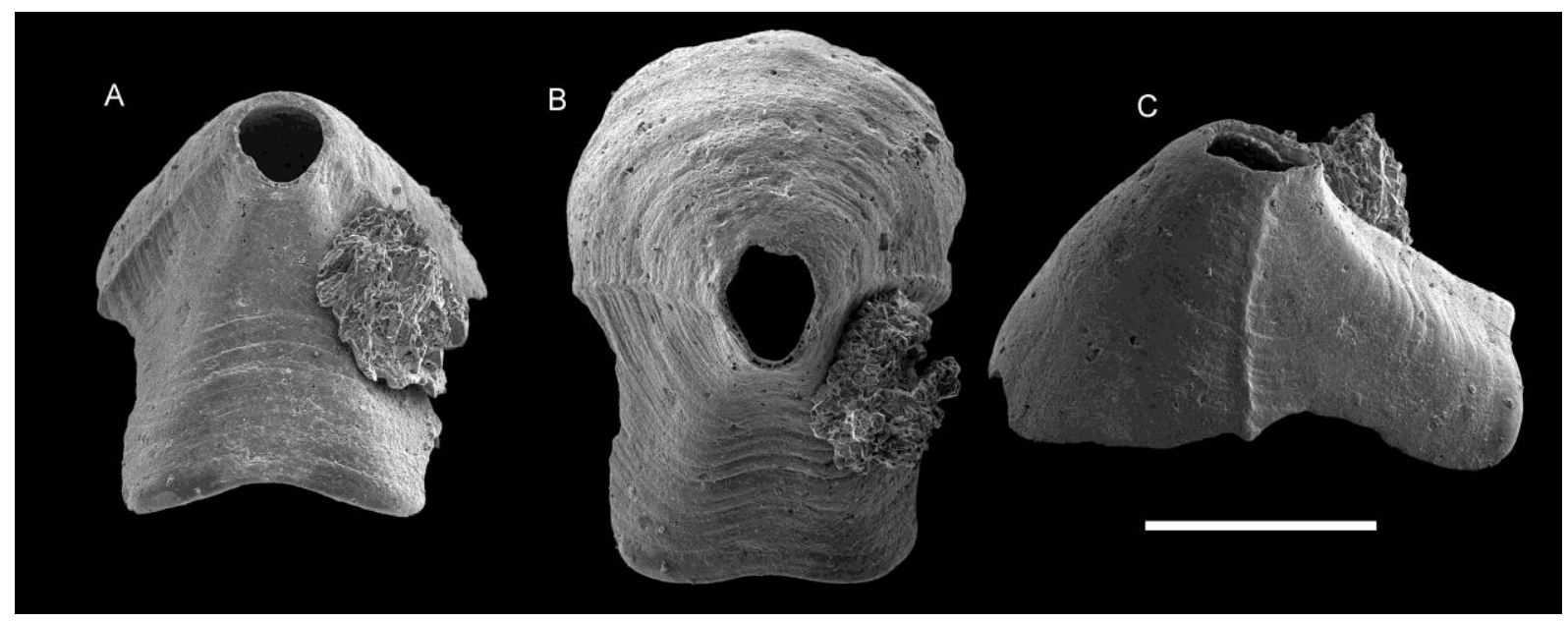

Figure 3 : Emargimantus angulatus gen. et sp. nov. SAMP 46313, phosphatised shell from sample Bun 9, ?Winnitinny Creek Member, upper Wilkawillina Limestone, Bunyeroo Gorge, Central Flinders Ranges, Arrowie Basin, South Australia. A, view of sub-apical side; B, apical view; C, left lateral view. Scale-bar equals $500 \mu \mathrm{m}$. 